SD 428 U.S. cong senate

- $A_{6} A_{3}$

appalachion forast reserw etc.

Wash., D.C., Apoull11, 1966 



\begin{tabular}{c}
$\begin{array}{c}\text { DET UUNGRESS, } \\
\text { 1st Session. }\end{array}$ \\
\hline \hline
\end{tabular}

\section{APPALACHIAN FOREST RESERVE, ETC.}

APril 11, 1906.-Ordered to be printed, together with the map.

Mr. Brandegee, from the Committee on Forest Reservations and the Protection of Game, submitted the following

\section{REPORT.}

[To accompany S. 4953.]

The Committee on Forest Reservations and the Protection of Game, to whom was referred the bill (S. 34) for the purchase of a nationa forest reserve in the White Mountains, to be known as the Nationa White Mountain Forest Reserve, and the bill (S. 408) for the purchase of a national forest reserve in the Southern Appalachian Mountains, to be known as the National Appalachian Forest Reserve, have given the same careful consideration and beg leave to submit the following report:

After a thorough discussion of the general subject it was deemed advisable to report an original bill in lieu of the two bills referred to the committee. This bill is substantially the legislation recommended by the American Forestry Association and the National Board of Trade, and it has received the indorsement of other organizations. It authorizes and directs the Secretary of Agriculture to purchase or otherwise acquire lands suited to national forest-reserve purposes in the Appalachian Mountains within the States of Maryland, West Virginia, Virginia, North Carolina, South Carolina, Georgia, Alabama, and Tennessee, and in the White Mountains within the State of New Hampshire, and to administer the said reserves under the laws governing national forest reserves.

There are suitable provisions in the bill for the purchase of lands, exclusive of the timber or mineral rights, for the acceptance of gifts of land, and for the reforesting of clearings wherever necessary for the protection of the soil or water supply.

To carry into effect the provisions of the bill it is proposed to appropriate an amount not to exceed $\$ 3,000,000$, which sum is to be available immediately and until expended.

The following argument, which shows the urgent need of the legislation proposed, was prepared by the Forest Service of the Department 
of Agriculture, and is submitted herewith as embodying the views of the committee:

First, the creation of these reserves is wise public policy. Between the census years 1850 and 1900 the population of the country increased from $23,000,000$ to $76,000,000$, or 330 per cent, but the money value of the lumber product which it consumed increased from $\$ 60,000,000$ to $\$ 566,000,000$, or 940 per cent. Both the per eapita consumption of timber and the price of timber are increasing. Both of the proposed reserve regions are chiefly natural forest land, more useful for the production of timber and water than for anything else. At present their forests are being rapidly destroyed. It is estimated that 24 per cent of the Southern Appalachian region has been deforested. Deforestation means loss of power to produce future forests. It is in the public interest that these lands should be acquired and held by the Government as permanent sources of timber supply.

Second. The acquisition of these lands by the Government will be good business policy. The use of the western reserves as productive forest is only just beginning, but the Government receipts from these reserves are approximating one-half the outgo. Within a short term of years they will undoubtedly carry themselves. At the same time their property value is rising and will continue to rise, both from the increasing value of the timber and from the greater productiveness of the forest under management. With a present value of not less than $\$ 250,000,000$, these western reserves are being administered at an annual cost of one-third of 1 per cent of this sum, while they are increasing in value fully 10 per cent a year. This is in addition to their enormous indirect returns to the public welfare from their indispensable relation to successful irrigation, to mining and other industries which demand lumber, to settlers, and to stock grazing. Both in the Appalachians and in the White Mountains, if the lands are acquired at present prices and in their present condition, there is an opportunity for the Government to establish reserves which will prove profitable investments under management, besides securing large benefits to the people of many States.

Third. The creation of these reserves, now or later, is a necessary policy. Sooner or later the certain consequences of the forest destruction which is now taking place will force the National Government to step in. The question is not merely that of preventing the impoverishment of the immediate localities and the conversion of productive land into a waste of barren rock. The loss of the forest is followed by that of the soil and by recurring floods. The headwaters of every important river south of the Ohio and Potomac and east of the Mississippi, including tributaries of these streams, rise in the southern Appalachians, while the White Mountains feed important rivers of every New England State except Rhode Island. The rainfall of both regions is heavy and distributed throughout the year. In the southern Appalachians it is heavier than anywhere else on the continent except on the northern Pacific Coast, and falls often in heavy downpours.

After denudation every rain turns the shrunken streams into mountain torrents, which devastate property and bear down vast quantities of silt to obstruct navigable rivers. The sand bars thus formed accentuate the effect of alternating high and low water periods, and large Government expenditures for dredging and harbor improvements are entailed. The clearing of river channels and harbors in North Carolina, South Carolina, Georgia, and Alabama is now being urged. Yet deforestation is only in its first stage. Eventually in this country, as has been the case in France, the stripped mountains will become so inimical to the public good that the Government will have to take charge of them and reforest them. But the expense of this, when once the forests are gone, will be only less ruinous than the damage which it will check, and the remedy will require many years to become operative.

France began a work of reforesting denuded mountains in 1860 , to repair so far as possible the damage which had followed the clearing of the forests under private ownership. By 1900 she had spent over $\$ 15,000,000$ and acquired over 400,000 acres of land in this work, while annual expenditures were still going on at the rate of over $\$ 600,000$ a year, and it was estimated that in completing the work the further purchase of over 425,000 acres of land and the additional expenditure of over $\$ 20,000,000$ would be required. Owing chiefly to the necessity of acquiring for protective purposes deforested land, almost one-fourth of the State-owned forest in France must be nonproductive for many years. By creating the proposed reserves now we shall secure a property which can be made to more than pay its way. If not created soon enormous expenditures without productive return will become necessary.

The creation of these reserves is in the interest of agriculture. After clearing, more or less of the land in the South is farmed for a short time but erosion is so rapid that within from five to ten years there is not enough fertile soil left to bear crops. Al]

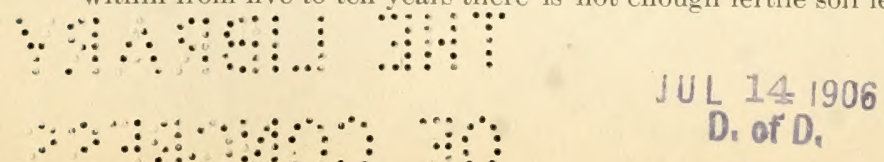


land that is truly agricultural will be excluded from the reserves. Such lands in the mountains themselves lie in narrow valleys along the streams, and after denudation are exposed to severe injury by floods. In the distant lowlands through which the waters pass on their way to the ocean the effects of deforestation are also felt in floods, which sweep out bridges, dams, and houses, and often spread barren sand over many acres of fertile fields. From April, 1901, to April, 1902, floods in the South, fed from the southern Appalachian region, did a damage estimated at $\$ 18,000,000$.

The ereation of these reserves is important for manufactures. The water power furnished by streams from these two regions is of greatimportance, both north and south, and will be more important with the development of the use of electricity. A gain of from $\$ 15$ to $\$ 30$ per year for each horsepower developed, on the basis of a ten-hour day, has been estimated as the alvantage of water over coal in point of economy. To the future industrial progress of the South forest preservation in the Appalachians is essential. The recent rapid manufacturing development, particularly of cotton manufaeturing, in North Carolina, South Carolina, and Georgia, has been largely assisted by the water power available.

In these three States alone cotton mills operated by water power are now established, which have an annual production valued at over $\$ 60,000,000$. A still greater future development, which additional water powers not yet utilized promise, is endangered. A water power which is intermittent is worthless under modern business conditions. The manufacturers whose observations extend over a term of years have discovered an appreciable decline in the volume of the streams. The water power of this southern region already developed or being developed is estimated at 500,000 horsepower. The undeveloped water power is probably not less than 1,000,000 horsepower more. If the forests are permitted to take their present course a very large part of this power will be lost, entailing a severe blow to the prosperity of the South and lasting detriment to the entire country.

The forests of both regions now contain a heavy yield of mature timber. They are highly productive forests. In variety and size of hard-wood species, the Southern Appalachian region surpasses any other natural forest in the country. The tendency under private ownership of forest lands, even under management, is to the production of small timber. In the lumber industry, from the nature of the case, the law of supply and demand does not fully guard the public interest. Both Germany and France at the present time find themselves confronted with a serious situation, owing to their neglect to provide at the right time for trees which would reach maturity and furnish saw timber now or in the immediate future. Enough land is in forest, but the crop is not ready, and in consequence alarm is now being sounded in both countries. Ownership by the National Government of the reserves now proposed will help to maintain for the future a supply of lumber trees of a large size.

The White Mountains and the Southern Appalachians are alike in being natural recreation grounds for a very large part of our population. Over 60,000,000 of the people of the United States are within twenty-four hours of the Southern Appalachians, and the White Mountains have long held a foremost place as a summer resort, especially for the Northern and Middle Atlantic States. Both of these regions should be guarded and handed down to the generations which follow. They are great natural blessings with which we have been endowed and which we must protect.

The question of the establishing of these reserves is not a local or a State question, but a national question. The interests affected are interstate. The evils which the reserves will check fall most heavily on distant communities, and even upon the National Government. Here again, if we are wise, we shall draw a lesson from French experience. In France the first efforts to repair the disastrous effects of torrents were made by engineers along the lower water courses. Dredging and dams, however, proved at best but temporarily effective. Only when they began to push their work up to the headwaters of the streams did they find themselves on the right road. The Government now puts into the building of levees and the improvement of navigation in rivers and harbors many millions of dollars annually. The reserves constitute a far more economical expenditure for the same purpose, in addition to their large contributions to the public welfare.

It is not right to expect the State within which these areas lie to reserve them for the benefit of other States. It is impossible for States which suffer from conditions outside their own territory to remedy them by their own action. There has been set aside in the West, for essentially the same purposes which these reserves will secure, a vast area of reserves created from the national domain and benefiting primarily the people of the West. But the interests involved both in the West and in the East are too broad to be regarded as even sectional merely. The benefits of the proposed reserves will be national benefits and their expense should be borne by the nation. 
THE APPALACHIAN FOREST RESERVE.

LOCATION.

The portion of the Appalachian region under consideration for the location of this reserve extends from Maryland southwestward, comprising parts of Virginia, West Virginia, North Carolina, South Carolina, Georgia, Alabama, and Tennessee, and lying between the Piedmont Plateau on the southeast and the Appalachian Valley on the northwest. It consists of parallel chains of mountains, as the Blue Ridge and the Alleghany on the southeast and the Unaka Mountains on the nortbwest, with an irregular mountainous table-land lying between. The prevailing trend of the system is from northeast to southwest. Numerous smaller ranges, separated by narrow valleys and deep gorges, extend between the principal chains, some parallel and others at right angles to the parallel ranges. The whole region comprises an approximate area of 17,500 square miles, having an approximate length of 350 miles, while the width varies from 35 to 65 miles. It is not proposed that the reserve shall embrace any considerable portion of this section, nor that every part of the reserve shall lie contiguous to all the others. The discretion is left with the Secretary of Agriculture to purchase such lands as may be readily acquired and such as will prove most adaptable to the purpose in view.

\section{RELIEF.}

This is preeminently a region of mountains, and is of paramount importance for physiographic as well as for forest reasons. It includes the most prominent geographic features of the Southern States and contains the highest mountains east of the Mississippi River. Mount Mitchell, in North Carolina, is the highest peak, having an elevation of 6,712 feet. Over forty peaks and 6,500 acres of land, lying in the Blue Ridge and Unaka mountains and intervening ridges, have an elevation of over 6,000 feet, while the whole region has an approximate altitude of 2,500 feet. The slopes, though steep, are seldom precipitous, being rounded and softened by age, and are mostly covered by a deep soil which is kept porous by the decaying vegetable matter, the mulch of the forest, and held in place by the roots of the trees, shrubs, and grasses growing upon it. In many of the transverse ranges, however, the bare and precipitous sides, carved from great masses of granite, lend a touch of variety to the scenery, and wherever the forests have been destroyed the soil, deprived of its support from the roots of the trees and the decaying leaves that cover it, quickly yields to erosion and yawning gullies scar the face of the hills.

DRAINAGE.

This region is drained by many large rivers, most of which rise in the Blue Ridge, for, though not the highest, this range is the oldest, and constitutes the divide for waters flowing east and west. On Grandfather Mountain, the highest point in the Blue Ridge, are two springs within a few feet of each other, the waters of one of which, flowing north, find their way by the New or Great Kanawha River into the Ohio and thence into the Misssssippi; while the other, flowing east. forms the headwaters of the Yadkin, which flows southeast through North and South Carolina and empties into the Atlantic Ocean. 
In this region rise many of the large rivers of the United States and all of the largest rivers south of the Ohio and east of the Mississippi. The James, the Roanoke, the Yadkin, the Catawba, the two Broads, the Saluda, and the Chatooga flow into the Atlantic; the Coosa and Chattahoochee into the Gulf; the New finds its way by the Kanawha into the Ohio; while the Tennessee, with its large tributaries - the Holston, the Watauga, French Broad, Big Pigeon, Hiwassee, and Little Tennessee-flow into the Mississippi. In addition to these dozens of other streams flow outward in all directions from this region and justify its claim to be considered one of the most important watersheds of the United States.

WATER POWER.

The descent of these streams is necessarily very rapid. Heading at altitudes of from 3,000 to 6,000 feet and leaving the foothills at from 1,000 to 2,000 feet, they must fall from 2,000 to 4,000 feet within the mountain region. Thus the Linville River, which rises on Grandfather Mountain, in North Carolina, descends at one place a distance of 90 feet in a linear distance of 100 feet, while in its whole length of $36 \frac{1}{2}$ miles, to where it empties into the Catawba, it has a total fall of 3,030 feet. This rapid descent of its streams has given rise to one of the most prominent topographic features which mark this region, namely, the deep and narrow gorges which have been cut through the mountain ranges, many of which are from 500 to 2,000 feet deep. The most noticeable of these gorges are those of the New River and Laurel Fork of the Holston River in Virginia; the Watauga, the Nolichucky, the French Broad, and the two gorges of the Doe River in Tennessee; the Tallulah River in Georgia; and the Big Pigeon, Little Tennessee, Nantahala, and Hiwassee in North Carolina.

The rock formation of the greater part of this section consists mainly of gneissic rocks, bedded slates, and limestones, having generally a northeast to southwest strike. But owing to the elevation and rapidity of the streams, the general course of the larger rivers has been but little modified by the geologic structure, and they lie directly across the strike of the rocks. The resulting conditions produce occasional falls and cascades, but for the most part the descent of these rivers is accomplished in a series of rapids which furnish opportunities for the development of ample water power by the construction of dams at convenient locations. Where the trend of the rivers lies along the strike of the rocks, as is the case in northern Georgia, the water descends by shoals and cascades, some of which are of great height, and large water powers could be easily developed. The following table has been compiled showing the possibilities in this direction:

\begin{tabular}{|c|c|c|c|}
\hline River. & $\begin{array}{c}\text { Estimated } \\
\text { horse- } \\
\text { power. }\end{array}$ & River. & $\begin{array}{c}\text { Estimated } \\
\text { horse- } \\
\text { power. }\end{array}$ \\
\hline 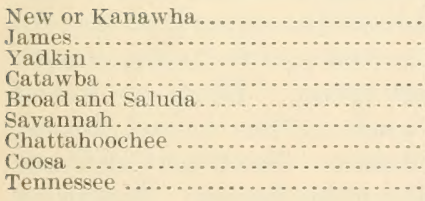 & $\begin{array}{r}60,000 \\
50,000 \\
60,000 \\
57,000 \\
43,000 \\
77,000 \\
115,000 \\
140,000 \\
100,000\end{array}$ & 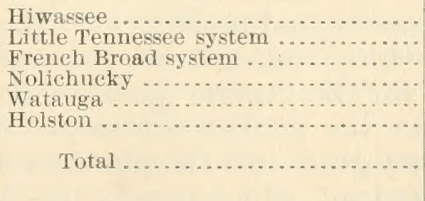 & $\begin{array}{r}75,000 \\
100,000 \\
50,000 \\
35,000 \\
20,000 \\
40,000 \\
1,022,000\end{array}$ \\
\hline
\end{tabular}


Estimating this power at $\$ 30$ per year for each horsepo wer developed we have a total of over $\$ 30,000,000$, the existence of which depends upon the regulation of the streams, and this in turn, as will be shown, upon the preservation of the forest areas.

Of course it is possible only to approximate this question. But it is certain, however, that on all of these streams large amounts of power could be easily and cheaply obtained. The average fall of the streams is great, being noticeably large at many places, while the low-water ffow, owing to the heavy rainfall and the storage effects of the great forests, is comparatively large. From the records of the United States Geological Survey a comparative list has been prepared, showing that the minimum flow of the rivers throughout the Carolinas and Georgia is larger per square mile of territory drained than on the rivers either of the New England or the Middle States. The lowest flow ever recorded on the Yadkin, the Catawba, the Broad of South Carolina, the Broad of Georgia, and the Savannah is 0.2 cubic foot per second per square mile, while the records show less than one-half this amount in the Susquehanna. It is estimated that 500,000 horsepower has been developed br is being dereloped along these streams.

The following table, taken from the Charlotte (N. C.) Observer of January 23, 1906, shows the amount of power now being used to operate cotton mills in the Piedmont regions of the Carolinas and Georgia:

Capital stock

$\$ 33,647,500$

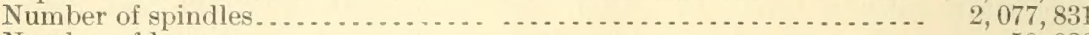

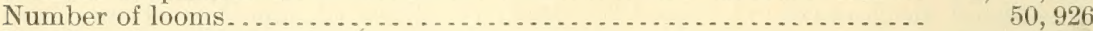

Number of employees . . . . . . . . . . . . . . . . . . . . . . . . . . . $\quad 45,685$

Number of horsepower . . . . . . . . . . . . . . . . . . . . . . . . . . . . . . $\quad 90,495$

Number of bales per year (counting 11-hour day) … . . . . . . . . . . $\quad 640,895$

Total annual value of production (approximate) $\ldots \ldots \ldots \ldots \ldots \ldots \ldots \$ \$ \ldots 4,060,776$

Only the cotton mills are considered in this table. If we include the other milling interests of this region and the varied interests of Virginia, West Virginia, Maryland, Tennessee, and Alabama, which are not here enumerated, the grand totals would be greatly increased. All of these interests are vitally involved in the preservation of the Appalachian forests.

FORESTS.

This region contains the largest and most valuable hard-wood forests in the United States. On its slopes were born the hard-wood forests, which, disappearing on the north by contact with the ice and on the south, east, and west from the encroachment of the sea, found here those favorable conditions of soil, elevation, and climate which contributed to their successful growth and continuance. One hundred and thirty-seven species of trees and a still greater number of shrubs and smaller plants have been examined and classified by Government experts. Among these the most valuable, from a commercial standpoint, are the black walnut, cherry, yellow poplar, chesnut, oak, beach, ash, magnolia, and mulberry. The oak, of which the principal species are the white, red, yellow, chestnut, Spanish, and spotted oak, constitute by far the greater portion of the timber trees. They are found mostly on the southward slope of ridges and on the lower slopes, where they grade into the pine forests of the plains. Next in abundance is the chestnut, which constitutes 17 per cent of the forest. Hemlock 
is found on the well-watered portions of the northern slopes and is most abundant at altitudes of from 3,000 to 5,000 feet. White pine is found as a valuable timber tree over the entire area, but is most abundant in the Unaka Mountains and the cross ranges. Poplar has a wide distribution, while the buckeye, beech, birch, maple, cucumber, and linn are most abundant on the northern slopes.

FUTURE OF THIS REGION.

This region is rich in minerals. It has limited but definite agricultural possibilities. The water-power possibilities, as shown above, are also of great importance, but the most important single resource of this section is its timber. The original forest was wonderful in the extent and variety, the density, size, and quality of its timber trees. Under present methods and conditions, however, this resource is being rapidly and dangerously depleted, and the three agencies that are contributing to its downfall are lumbering, forest fires, and clearings for farm purposes.

LUMBERING.

Lumbering operations are widespread, and, though primitive, the methods show a reckless disregard for future growth. A clean lumber job is seldom seen. Trees are felled without regard to the young growth. The logs are "snaked" down the hillsides with mule teams, breaking down the young seedlings and wearing deep trails in the sides of the hills, which are soon converted by the heavy rains into yawning gullies. The tops of the trees and the branches are left on the ground to rot and become the breeding places of innumerable insects which attack the living growth. Under Government control this industry, directed into proper channels, would insure the preservation of the forests, furnish a valuable object lesson to private ownership, and contribute materially to the support of the reservation.

FIRES.

The dried branches and tops of felled trees also furnish ready material for the spread of the great forest fires which constitute the second agency contributing to the destruction of the forests. Fires, of course, have been prevalent since the days of Indian occupation, but it is only in recent years that they have been attended with such disastrous results. Grazing is an important industry in this region and the idea is prevalent that pasture lands are improved by being burned over yearly. Fires are started also by farmers to help in clearing new patches of land, and no attempt being made to check them, they creep through the forests year after year, scorching the butts and roots of trees, destroying the seedlings, and burning up the forest litter and humus. The effect of these fires is seldom appreciated, inasmuch as they do not often kill the larger trees. But where the spring fires are of yearly occurrence it is impossible for the seedlings to grow. Under such conditions a forest can not reproduce itself. As the trees die out or are cut for lumber, they are replaced by worthless shrubs and brush that sprouts from the roots. 
CLEARINGS.

Greater than either of these agencies in contributing to the destruction of the forests is the damage done by clearing, for agricultural purposes, lands which are not fit for farming lands, but should remain forever in forest. From year to year the farmer, abandoning his worn-out fields, moves up the side of the hills, clearing additional patches which can not at best last more than four or five years. After the trees have been deadened and the shrubs removed, corn may be planted on the patch for a year or two, then grain for a year, grass for a year or two, then it may be used as a pasture for a year or two, after which its usefulness is over. During this time the color of the soil has gradually changed from a dark gray or black to red, as it loses its organic matter. Becoming more and more impervious to water, it yields to erosion, and the field is given over to weeds and gullies.

The tan-bark industry is also a growing industry in this region. Every year thousands of cords of bark are shipped from this section. stripped from the trees, which are either left standing to die or are left on the ground to rot.

FLOODS.

Thus the lumbermen, the forest fires, and the farmers have cooperated to destroy these forests. Already serious damage has been done, and a continuance of present methods and conditions must inevitably, in the near future, result in the destruction of this great natural resource of the Southern Appalachians. But these agencies have not only contributed to the downfall of the forests; they have made possible the serious floods that have of late years characterized the rivers that flow out of this region. In the virgin forests the ground is covered with a blanket of decayed vegetable matter, often a foot or more thick, the mulch of the forests, which acts as a sponge to absorb the water that falls upon it. The branches of the trees break the force of the rainfall, and their roots, extending deep down into the soil, when decayed, furnish a network of underground channels which take up the water, and weeks later send it out as innumerable springs at the foot of the hills. Here, where the rainfall sometimes reaches a total of 105 inches in a year, nature has provided this sponge, which acts as a great reservoir, storing up the water and feeding it out slowly and regularly to the streams that have their source in these mountains. But where the fires have consumed this humus or sponge, and where the soil has lost its organic matter, as in the abandoned hillside clearings, no check is opposed to the force of the waters, which, sweeping down the steep hillsides, flood the rivers, sweeping away bridges, dams, and mills, destroying public roads and fertile valleys and filling up navigable streams with the silt brought down with it. It is estimated that the direct loss by flood in this region from April 1, 1901, to April 1, 1902, amounted to $\$ 18,000,000$, and as the forest destruction continues these floods will become more and more disastrous. The destruction of the sponge reservoir also affects seriously the low-water flow of the streams and threatens to destroy the value for water power. The protection and preservation of the great natural resources of this region resolves itself then into this - the protection and preservation of the forests. 
CONCLUSION.

The application of practical forestry to this region would not only preserve the productive apacity of the forests, hut would protect the water power as well and would go far towad preventing the frequent recurrence of disastrous floods. Protection from tire is praticable without great expense, the hard-wood forests of this region being by no means so inflammahle as the coniferous forests of the North and West. Inder faromble anditions the reprodurtive nower of these forests is remarkable, and a reservation would soon become selt'-sul)porting from the sale of timber. An a health resort, no region oflers more natural facilities. W'ithin twenty-four hours of $60,0(10,000$ people it would become one of the great vacation grounds of the nation.

The rarious States in which it is proposed to locate this reserve have already by legislative acts conferred upon the L'nited sitates Government the right to acquire tithes to these lands and exempted them from taxation. They can not, on account of the proposed location of the reserve in more than one sitate and their own lack of funds, be expected to ge much further. Nor ("an we look to the individual landowners for any improvement in present methods. Only cooperation on a large scule, such as (rovermment ownership) would insure, can stop this mwise cutting, regulate clearings, prevent disastrous fires, and preserve to the nation the great natural advantages and resomres of this wonderful region.

HISTORY OF SOUTHERN APPALACHIAN RESERVE LEGISLATION.

1 pil $\approx 1,1900$.-- Bill by Senator P'ritchard providing an appropriation of $\$ 5,000$ for a preliminary investigation.

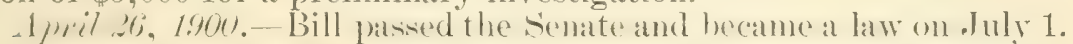

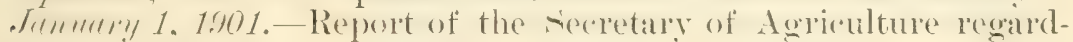
ing the preliminary investigation made ent to congress.

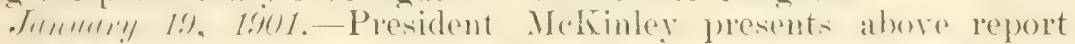
with a sperial mesage reommending its faromable consideration by Congress.

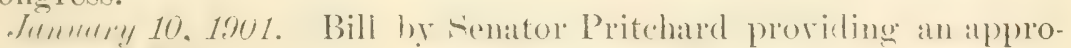

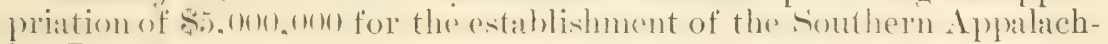
ian Reserve.

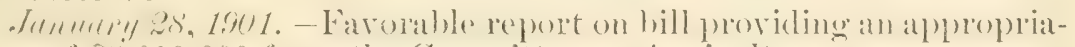
tion of $\$ 5,000,000$ from the Committee on Agriculture.

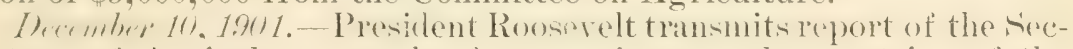
retary of Agriculture on the forests, rirers, and mountains of the Southern Appalachian region to C'ongress with resommenciation that Congress consider it favolably.

In arddition to the foregoing a hill in 19 (n) passed the I nited states Senate but the House took no action on it.

\section{THE WHITE MOUNTAYN FOREST RESERVE.}

The Irhite Mountain region, in which hy fal the lareger part of the proposed White Mountain Forest Reserve will lie. covers an area of apploximately $\$ 12,000$ acres, most of the land heing fal $\cdots$ hetter suited to forest production than to agricultural use." The three principal ranges of mountains contain nine or more peaks orer 5 , (n) feet in height. In the Franconia Range, to the southwest Iount Lafayette 
towers 5.259 feet. flanked by mountains of nearly equal altitude.

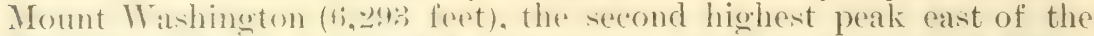
Miscissipui liver. ocempies a conspicuous position in the lofty Presidential Range in the center. while the ('arter Range, to the northeast. although not so high as either of the other ranges, contains peaks of very considerable elevation.

Formerly this entile region, with the exception of the summits of the highost mountains, was corered with a dense unbroken forest that stretched without interruption to the northern limits of the State, and even now the greater part of the region is forested, though clearings have heen made along the railroads and in the river valleys. It must not he supposed. howerer, that all of this growth is timber or even destined to become timber in the course of time, for careless lumbering aml repeated fires have in some places worked havoc with the forest cover, and the growth there is of a worthless character.

THE FORENTS

The lower slopes of the momtains, up to an altitude of 1.800 feet. and rately extending heyond $2, f(0)$ feet, are covered with a growth of hard woods typiral of the region and latitude - the hard and soft maple, rellow and white birch, and beech, to name only a few of the more common. From 1. rem to : 50 no feet the red spruce, the most raluahle of all forest tress in northern New Hampshire, predominates, though mixed with bakam (fir) and some of the hatrdier broad leafed species.

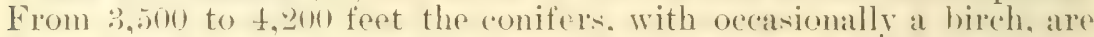
alone able to make sucersiful srowth. while above t.2uin feet we find only a serubby stand of balsam, prostrate shrubs, and bare rock.

The chameter of the growth depends somewhat on the aspect of the mountains and their aratient, but in general the four forest beltsabove named are traceable throughout this region.

More than 1 sol different speceies of woody plants grow in New Hampshire. many of these of great commercial value, but the forests in the north of the state are preminently forests of conifers. unlike the tim-

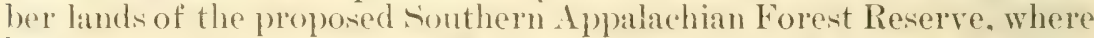
hard woods predominate. Of the eonifers, the red spruce, as above stated. is hy far the most raluable. It represents 8.2 .5 per cent of the total cut of all species. Balsam and white spruce (the latter in the extreme north). tamarack, white cedar, hemlock, and white pine (in the south) are the other soft woods that make up the hulk of the forest.

In Alhany and Waterville, on the southern edge of the region under discussion, the stand of spruce is the heariest in Few I Iampshire, being 90 per cent spruce and s per cent hireh on the lower levels. Here, in the Connecticut Isake region on the north, in the upper part of the Magallowat River hasin (the best timbered watershed in the State), and on the northern and eastern slopes of the Presidential Range, are the only considerable tracts of riroin forest now standing. The total area is not far from 200,000 acres.

The total stand of soft woods in northern New Hampshire is estimated at 4,764,000 feet, board measure.

SCENERY AND CLIMATE.

To attempt to describe the scenery of the White Monntains-the "Switzerland of America"- would not only be superfluons, but would 
be out of place in this report. Of the many "notches" in the hills, each has its own cham. The rugered and joredpitous Crawforl, or White Momotain Noteh, at the rery hase of the Prosilential Range: the enentler slopine Franconia Noteh, with its - ()ld Man of the Mountains:" the l'inklian Voteh, with filen Ellis Falls, and the statling Dixville Noteh, in the north, produed hy some titanic convulsion of nature long aco, have attractions that are not rqualed east of the Rockies, while the towering stmmits of the White Hills and the ereenclad slopes of the momtains farther south, interspersed with lakes and streams, afford each year to many thousands from all orer the country unrivaled opportunities for rest and recreation.

Is a summer resort the White Momtain region is without a peer. This region is within a day's easy travel of more than 10,00(1),00(0 people. who have been yuick to take adrantage of the opportunities given them. It is estimated that the returns from the summer-resort business alome in this one State amount to move than $\$ 8,000,000$ annually.

The existence of this region as a health resort depends directly upon the preservation of the forests, either absolutely or through conservative lumbering. 'The denudation of the timber lands is followed very frepuenty by an invasion of fire: the fer remaining trees are destroyed; the very soil in some cases is consumed, and the rivers at their sources berome at hest feeble and intermittent. When the forestis are gone and the streams have dwindled the mountain region will no longer be a desirable place for summer residents, and they will be compelled to go elsewhere. This is no ronjectme. Beyond doubt many people who formerly frequented the II hite Mountains now spend their summers in C'anada for no other reasons than those named alove.

The climate of the White Mountains, thomgh cool, is dry and bracing, tempered hy plevation and proximity to the sea. Fion this is dependent in a laroe measure on the preservation of the forests in their substantial integrity.

RIYERS ANI) L.AKES.

The IThite Momtains constitute the yeat watershed of the New England states. Five of the principal rivers of this section of the country rise or have important tributaries that origrinate there, and all of the Vew England states sare one. Rhole Island. are concerned in the preservation of their even flow.

The (omnecticut is the largent river in New England. Rising in the comnecticnt lakes. in the extreme northern part of New Hampshire, it forms the boundary between that state and Vermont and, flowing through Massachusets and comnecticut, empties into Long Island Sound, : 55 miles from its somre. The drainage basin covers, approximately, 67\%.179 acres. The most important tributaries of the river in noithern New Hampshire are the Upper Ammonoosuc. Istacls River, and the Lower Ammonooste, all of which rise in the White Hills.

The Nerrimac River is formed he the junction of the Winnepesankee and Pemigewasset rivers at Frinklin, N. I., about 110 miles from its mouth, at Newburyport. Mass. The Winnepesaulee River drains the lake of the same name, the largest natural reservoir within the boundaries of the State. The Pemigewasset River, with its numerous trihutaries. reaches into the very heart of the White Mountam region, 
receiving the drainate of the larger part of the Franconia range as well as that of two rerre considerable lakes. squam and Newtound. 'The dranage hasin of this river (the Pemigewaset) covers 343,512 acres.

The Androscogoin River loceives the drainage of the extensive Rangeley chain of lakes, most of which lie in Maine, hut many important tributaries, particularly along the Magallowa and on the Androsoggrin proper, in the vionity of Berlin and forbam. recoive their waters firom the New Hampshipe mountain sistem. The dranage basin of this river cover's 480,272 acres.

The sare, the fourth of the rivers that drain the territory under discussion. rises in the heart of the ('rawford Noteh and flows southeast. (mupt ring into the sea below sico and Biddeford, Me. Its drainage ham. within which are several extensive lakes. covers $4+4,435$ acres. and the major part of its watersare received from the mountains of New Hampshire.

A tifth river, the Piscatayua, forms for some distance the boundary hetween New Irmpshire and Maine and furnishes considerahle water power on its upper reaches.

New Ifampshime as a whole is singularly fortunate in the number of lakes and ponds that constitute natural reservoirs and assist very materially in preserving continuity of flow in rivers and smaller streams. but in the immediate vicinity of the region where the larger part of the proposed reserve should be established these natural reservoirs are entirely larking.and the streams depend for their constant supply on the waters stored in the spongy duff that forms the forest floor and kept from evaporation by the dense shade of the forest corer.

The water power developed alomg the tive rivers that are thus primarily dependent for their supply if water on the perpetuation of the forest is enormous and nowhere has it been fully utilized.

The Comnecticut, spraking only of the main river, hats a total fall of

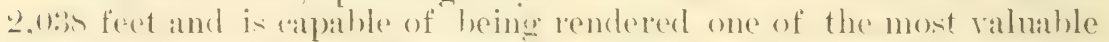
rivers in the worlel. "The power developed at Holyoke, Mass. is the largest in the country, except that at Niagara."

'The Merrimac, as a source of water power, is justly famous. The total fall of the main river is zhit foet in 110 miles. the fall being concentrated, however, at six principal points, thus giving maximum

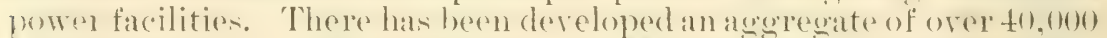
horsenower at Lowell, Lawlence, and Manchester, and on the tribu-

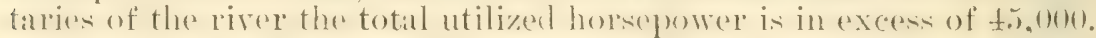

Brunswick, Auburn. and Lewiston, in Maine, and Berlin and Gorham, in Vow Hampshire, are important manufarturing towns on the Andrescogerin; Sace and Bidefeford on the Saco; and Dover and Somersworth on the Piscataqua and its tributaries.

The population of the thirteen rities and towns mentioned was, in

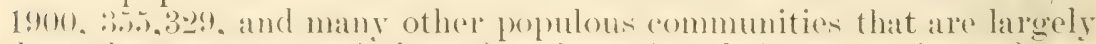
dependent upon one of these fire rivers for their prosperity and usefulness ande be enmerated. Moreorer, the fart that the supply of drinking water for sereral of these centers of population is taken from the streams named should not be overlooked.

All of these tive rivers aro of value for purposes of navigation, and the agricultural industries along their hanks are of no minor importance. 
Rainfall and water storage.- The average annul rainfall in New Hampshire is about to inches, and this amomnt has raried but little in the years since observations were tirst made, hut $\cdots$ it is the amomut of water that passes inte the soil, not the amount of lainfall. that makess a region garden or desert."

It is not claimed by the adrocates of this bill that an increase or decrease of the forested area will in any way atfect the total rainfall forests appear to be the result of rainfall rather than the reverse-but it is contended that ". the forest is the most effective acent known in regulating the disposition of the presipitation after it reaches the ground."

Water escapes from the eround mpon which it falls in one of four ways - hy transpiration, eraporation, surface run-ofl. or seepage. The presenee of forest may incerese slightly the amome of moisture that is lost through transpiration, hut this is more than offect by the greatly increased retentiveness of the soil due to the presence of the forest cover.

The shade of the trees and the obstacle they oppose to the foree of the winds materially lesien the evaporation. Eurepean olservations covering many reats show that evaporation from wet surfaces on the floor of the forest is but one-third or one-fourth that from similar surfaces in the open.

The branches and leaves of the trees break the foree of the rain and extend the period of tinje during which it reaches the soil. The foree of the impact is thus derereaned and hardening of the forest floor prerented. The roots and trunkis of the treses also tend to hold in platee the accumulation of litter which alsorhs the rain and melted snow and greatly reduces the surface run-oft.

The principal arenue of escape for the water from a forested area is. therefore, through seepuge. The water is given off eradually from the ground. and the flow of the streams is thus made even and permanent.

Forests are a most important factor in preventing floods and the succeeding droughts. That New England has not suffered more severely from the former is due perhaps to the fact that her river beds are generally deep and capable of containing an amount of water much in excess of the arerage flow, but the Amoskeag Manufacturing Company, at Manchester, N. II., some years ago, it is said, lost more than $\$ 100,000$ from a freshet, and other instances might he named. Droughts, too, are not uncommon.

In Bulletin No. 7 of the Forestry Division, United States Department of Agriculture, published in 19(1)2, are given a number of wellsubstantiated examples of forest influences in this country. A few will suffice for a proper understanding of the subject:

In the rear 1881 the state of New Hampshire established a forest commission, who were instructed to incuire, among other matters relating to the forests, into "the effect, if any, produced hy the destruction of our forests upon our rainfall, and consequently upon our ponds and streams." In their report, marle in 1885 , the commission presented a summary of the large number of replies to their inquiries. These replies came from all parts of the State. From the summary the following citations are made:

"Beginning with the sonthern portion of the State, and with the town of Richmond, attention is called to a small stream there, which in 1865 furnished suflicient power for four sawmills nearly all the year, but which began to dry up with the more rapid removal of the timber occasioned by the introduction of steam as an 
auxiliary power. The water and the woods have disappeared together, and the same is the case in other portions of the town.

"In Fitzwilliam and Rindge the same results have been reached all the more rapidly herathe of the nearer proximity of these fowns to a market. Well-known trout streams, once abundantly stocked with fish, are now dry half of the year, and the treeless ground and naked rocks along their banks and about their sources are considered a sufticient explanation.

"The chairman of the board of selectmen in Henniker, who has given much attention to the subject, is confident that the water in the Contocook River has decreased fully one-third within even twenty years, and that the tributaries have fallen off still more, many being nearly dry in the summer. During this period $\$ 75,000$ worth of timber has been cut within this one town. In the surrounding towns, also, the timber has disappeared with equal rapidity, and the water supply has seriously decreased.

"The report from Bow, which covers a period of fifty years, within which most of the timber has been cut off, and that from Hopkinton, which covers a period of sixty years, both tell the same story of naked hillsides and diminished streams.

At Hanover the Connecticut River for many years has been decreasing in volume, and with increasing rapidity the timber from its headwaters has been floating by.

"In Canaan sixty-five years ago there were nine or more mills of different kinds; abundant water power all the year around; no thought of reservoirs or double dams, or precautions against drought. Canaan street, now covered with a firm, dry sod, was laid out through a swamp, impassable but for the hummocks and fallen trees, while dense forests of giant trees covered the hills. The writer who furnishes the above facts, a native of the place, returning after an absence of thirty years, found the hills and rocks bare, the springs choked up, and the mills oblined to resort to steam power or lie jdle.

"The great mountain region of the State lies in contiguous parts of the counties of Grafton, Carroll, and Coos. The numberless streams originating in this region, protected by the primitive forest, might be thought to be heyond any disturhing eauses, but such is not the case. The town of Littleton depends upon the Ammonoosuc for its water power, but three of its oldest citizens testify that this power has diminished one-third within fifty or sixty years. The mountain forests during this same period have been encroached upm as never hefore, and it is not surprising that so commonly these two facts are associated as cause and consequence.

"Coos ('onnty contains more of the first growth of timber than any other portion of the State. In the midst of this region are the sources of the Connecticut, Andros(o)grin, Faco, and their many tributaries, and a diminished water supply at this point is felt throughout the course of these important streams. The report from Jefferson is that the older inhabitants atresethat thestreams are sulaller than formerly.

"An intelligent observer at Berlin, on the Androscoggin River, makes the following important statements, covering a perion of twenty-six years. Within a ralius of $t$ miles from his residence are eight streams or brooks and two ponds, and the the water in each during the above period has materially diminished. As an illustration of the connection between the removal of the woods and this diminished supply, he adds that 'six rears ago he supplied his stock with water from what was then an unfailing brook, by means of an aqueduct which furnished 300 gallons per hour. Now that the trees along the stream have been destroyed by the woodman's ax and by forest fires, his water supply is cut short in summer by drought and in winter hy frost. Ilumdreds of acres of timber have been cleared within these six rears in the same vicinity.',

At Lancaster, the county seat, on the Connecticut liver, an old resident reports " an alarming decrease in the water of the streams and springs during the past sixty years, and esperially luring the last twenty-fice vars, within which periol the smaller timber also has been removed. Israels River in his boyt ood was a large mill stream 8 or 10 rods wide, with sufficient water to carry a very large amount of machinery the year round. Now it is an insignificant stream, with, from May to November, not more than half the water it had fifty years ago, and not more than two-thirds there was twenty-five years ago. Other streams have suffered in the sameway, and the springs have, if possible, suffered more than the streams. Many, once thonght to be never failing, are now for long periods dry. That the cutting off the forests accounts very largely for this change he considers as sure as that effect follows cause, and the result is hastened by the reckless methods in use. Instead of cutting timber that is matured, everything is cut to the size of 5 or 6 inches in diameter, and what remains is cut into firewood or burned at once, leaving a dreary waste." 


\section{PURTOSES AND BENEFITS OF 'THE RESERVE.}

\section{PRESERVATION OF FORESTS.}

The first areat object of a forest reserve is the perpetuation of the varions speries of trees that are fomd within its limits for the use and enjoyment of future generations. It must not be supposed that a forest. once rlealed, will reprouluce itself always, or even generally in like form. In unculled forests of conifers, reproduction of soft woods is usual. but where hard woods are mixed with conifors, the second crowth comsists laterely of the hroal-leafed species, owing to their faster rolative growth at tirst and the greater ease with which they are seeded. Only on the upper slopes is the reproduction generally in conifers.

Therefore it am readily be seen that the total area of soft woods is constantly diminishing, and when tire comes in to further complicate the processes of nature the end of the spruce growth seems in sight.

Even when allowed to reproduce without let or hindrance, few of the valuable species of soft woods become merchantahle in less than sixty to one hundred years. "At 3,0$)(1)$ feet it takes a spruce tree one humbled and twenty-tive years to become 6 inches in diameter."

Under private ownership no such conservation of the timber supply as is necessary can he had: Impelled hy the desire for immediate returns from their investments and feariug that any moment their holdings mar he seriously depleted by fire it is matural that the owners of forest lands should have but little interest in future crops not to be harvested in their lifetimes. Operators of the larger paper, pulp, and lumber mills in New Hampshire, however. have in some instances come to realize that the perpetuity of the mills depends direetly upon the productive capacity of the forest, and initial efforts are being made, through the appliation of correct forestry principles, to insure an endless supply of raw material.

These individual efforts of necessity must proceed rery slowly, and hefore the entire threatened area cain be brought under private conservation irreparable damage will have been done to the forest cover, which is of primary eronomic importance to all New Enoland.

\section{PRESERYATION OF WATER POWER.}

The forests of the White ILmutains, as has been shown, have a direct effect on the water power of five of the New England States. 'Their preservation hy Federal atction, as a matter of farsighted economy, would he justifiable on this ground alone.

\section{PREVENTION OF FIRES.}

On the prevention of forest fires rests the whole problem of valuable second growth. Fire is more destructive than man; it is the greatest enemy of the forest, for not only does it destroy the standing timber and other merchantable material, but the young growth, the seedlings, the seeds, the leaf litter, and even the soil itself.

The causes of forest fires. in order of importance, are: Railroads, carelessness in clearing land, tishermen, campers, and maliciousness. Owing to the fact that the two dangerous seasons of the year, in New 
Hampshire, are in the early spring and fall, more fires are set hy the negligence of sportsmen than would at tirst seem posible, but jrobably more fires are caused by railroads than by all other agencies combined.

New Hampshire forest have been visited repeatedly by destructive conflagrations, though the topography of the country forbids the occurrence of any tire so far-reaching an the Miramichi tire in New Brumswick in 1825 . The Zealand valley has heen several times burned over and no part of the State has been entirely free.

The spring of 190:3 was particulary dry, the total precipitation was much below the normal, and the prevailing winds were musually high. As a conseguence fires, kindled ty the various agencies above named, swept over New IIampshire in every direction. Eighteen thousand acres were burned over in the townships of Kilkenny and Berlin alone; St.n(n) acres in the White Mountain region. including, it is estimated, $3(1,(10)$ acres of valuable timber land, and more than 200,000 aceres in the entire state. The total losi was not far from half a million dollars.

The effect of tire, if it does not entirely destroy the floor of the forest and so prevent the return of tree growthexcept after long rears, is to permanently change the character of the forest cover. The soil is leeched hy rains, and many of its valuahle constituents ale washed away. All young conifers are killed, to be reproduced only from seed carried hy the winds. and the land springsup to the more resistant and more rapid-growing species, such as hard woods, poplars, and the worthless hird cherry and s(ruh oak, which lieep out all valuable crowth for from fifteen to twenty years. ".'The tendemers of a repeated bum is to increase the number of (ralueless) hard woodis present."

The law of New Inmplire relating to forest fires.their prevention and control, are good: but forests owned by private partien are not policed as they should be, and only under public ownership (an proper precantions be taken. The fire problem in the IThite Mountain region, it is expected. will be speedily solved if the proposed reserve is established.

\section{FOREST INDUSTRIES IN NEW HAMPSHIRE.}

It is a very remarkable fact that "instead of reducing their per capita wood ionsumption as the supplies become less and dearer and iron and steel cheaper all civilized nations have within the last forty year's constantly increased their wood consumption at a rate of from 3 to 5 per cent a year.'

A very large wood-consuming population is within easy reach by land or sea of the timber lamds of New Hampshire. Probably the forests of this region are more intensively lumbered than those covering an equal area in any other part of the United States.

The wooded area of New Hampshire in 1900 was estimated at $3,268,000$ ares. The total amount of timber cut for lumber was $570,357,000$ feet. hoard measure, or $17 \%$ board feet per acre of wooded area, this being the largest cut per acre recorded in any State of the Union. Wisconsin follows with 175 hoard feet per acre: Pennsylrania with 163 ; Ohio with 161 ; and so on down to Texas with but 15 board feet cut per acre of wooded area.

Obviously these figures show fairly aceurately the extent to which the lumber industry is using the forest resources of a State. New Hampshire is unquestionably using her's at a rapid rate. 
And the finct that the arelate quantity of merchantable timber to

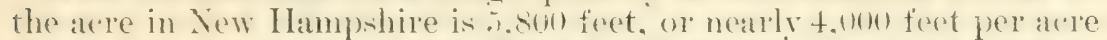
larger than the arerage stand of the Mane forets, probahly explains the intemsity of the commereial atsialt on New lampline simbered aroa. In addition. the topogeraphy of the states chief forested areat. namely. the section under discussion, is such as to render lumbering

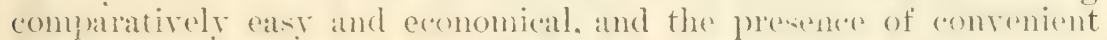
trumk lines of railiond greatly facilitates the marketing of the manufactured product.

The (appital invested in the palper and pulp industries incerased from

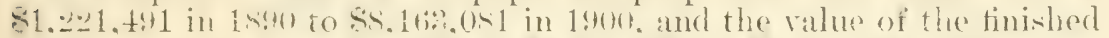

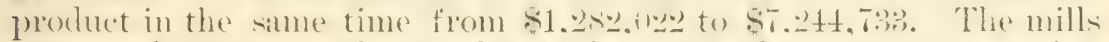

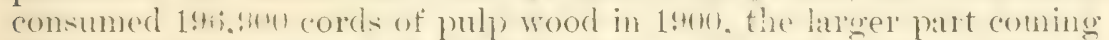

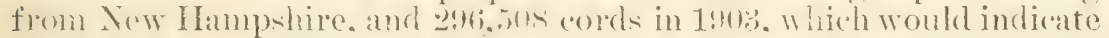
that the ralue of the finished product has increased by a third in the lant theere years. The combined holdings of timber land of pulp and paper millis in northern New Ilampshire are trs.ent) acres, including the great bulk of the virgin forest.

The capital invested in the lumber industry in New Hampshire was, in $1900, \$ 11,3 \$ 2,114$. with a product valued at $\$ 9,218,310$.

Conservative lumbering. under poper regulations enforced hy (tosermment ownership, is necessary for the perpetuity of this great and convenient supply of timber.

\section{INCONE FROM RESERVE.}

Lastls, it may be said that the establishment of the proposed reserve will he an inrestment that is destined to result in safe and substantial returns

Sistematic removal of the mature trees in a forest will bring in a constant revenue, and will at the same time in no wise interfere with adrantages attendant upon the preservation of the forest cover.

- Scientific forestry in (iemany. France, and Italy gathers an ammal crop from the trees. which have leached the point where they are commercially raluable and an be cut, not only without injury to, hut, on the contrar 5 . for the benefit of the whole forest, of from $\$ 1$ to 55 an acre per rear net after paying all the expenses of their care." The Swis forests " rield net to the (iovermment so per acre a rear." and the statement is made that one of our western reserves. in lome, rielded an income of 500 , wh over and ahove the cost of its protection.

The total income from the forest reserves of the Lnited states in 1905 was about $\$ 500 .(100)$, a remarkableshowing in riew of the fact that the forest service has only recently undertaken to exploit the resoures: of the timber lands under its control.

In New Iampshire the remmant of virgin forest in the Presidential Range is in a compact area; it will be posible, if preserved. to operate. this tract immediately for revenue. One hundrer and ten thomsand acres will corer all the threatened area, including the cntire hull: of the Presidential liange. some $60.0(1)$ acres. Deducting the land alrouty under leserve-ahout one-fouth of the whole-held by hotel companies. railroads, or as farming land, and not to be considered here. there remain so,fon acres of forest and ledge to he taken. Included in this acreage is some denuded territory.

S. Rep. 2537, 59-1—2 
Conserativer extimated, the averate ammal increment of standing

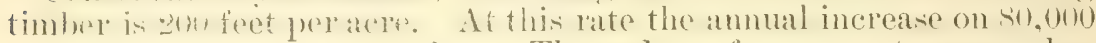
acres is some $16,000,000$ feet. The value of spruce stumpage has increased in recont years from $\$ 2.50$ per 1,000 feet to $\$ 6$ or $\$ 5$ per

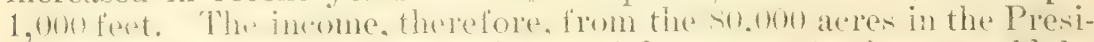
dential Range, at the low estimate of $\$ 5$ per 1,000 feet, would be $\$ 80,000$ anmually.

\section{A FEDERAL MAT'TER.}

New York and Pennsylyania have purchased large areas within their boundaries as State forest reservations. 'To protect the waters Howing fom the White Monutain rowion and to romere the supply

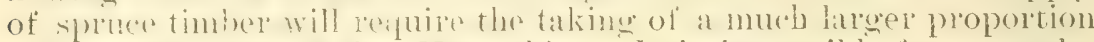
of the small state of tow Inamplime. It is imposible for a population mostly farmers, few of whom acquire wealth, to set aside and mantain aroge a portion of their chomain for a revervation for the country at large.

Vew Hamplare own no public lands. The rivere which hate their

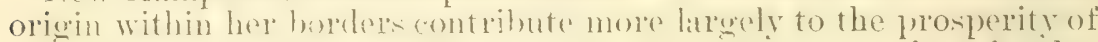

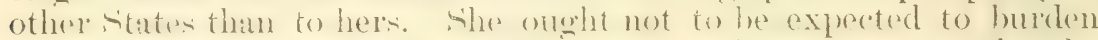
herself with deht for the hemelit of her noightors. nor wan they he

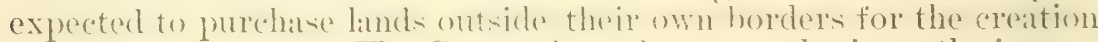
of a forest reserve. The Connecticut, for example, is vastly important remomirally to the siater of Vermont. Mar-achusetts, and connectirut. Int none of these states ean rightfuly he asked to contribute money to be invested entirely within a sister State.

The (fovermment dow mud in many ways or weale wath for the people. But, molike the oreat rxpenditures for river and havhor improvement and for irrigation, this is a loposition not for the creattion of woalth hut for its preservation. The adrantages to be gained are not lisal and temporary. hut destimed to hring hemefit to many States and to generations yet to come.

since Ls:1 the National forromment has been committed to the establishment of forest reservations, and at present approximately

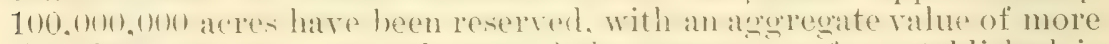

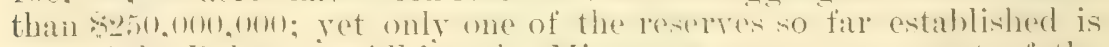
east of the I Dakotas. All but the Minmenota reserve are west of the one humberl and third meridian. while at present more than ninetenthe of the population of the L'nited States in found east of that line.

France has involved herwelf in vast "xpenditures for the reforesting of a latere momtain area, ande Italy is similarly engaged. It coster the

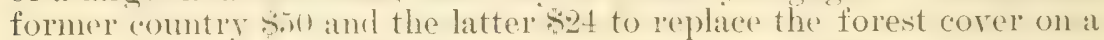
single are, and this is expected only to start the growth of the new forest. It will he at least half a century before the reforesting will be measurahly benceficial. Even then the character of the forest floor will be far from ideal, and centuries will be needed to effectually bring back the qualitios that make it of such sleat ecomomic value to the lands below.

It is not the main purpose of this hill to reforest the proposed reserve, but to protect the forest cover already in existence.

The demand for inmediate action is imperative if the remaining rirgin timber in the White Momtains is to be preserved. Quite as 
great is the demand for proper regulations to control the cutting of the secondatry growth and to prevent the depredations of fire.

The magnifient forest system of (rermany, as exemplified particularly in the Black Forest. commends itself to rerrestudent of the forest problem, and it is evident that the viational Government alone can undertalie and sucessfully carry through works of this magnitule. 

LIBRARY OF CONGRESS

||| || || || || || || || || || || || ||

|| || || || |||||||||||||||||||

๑ 0008978530 


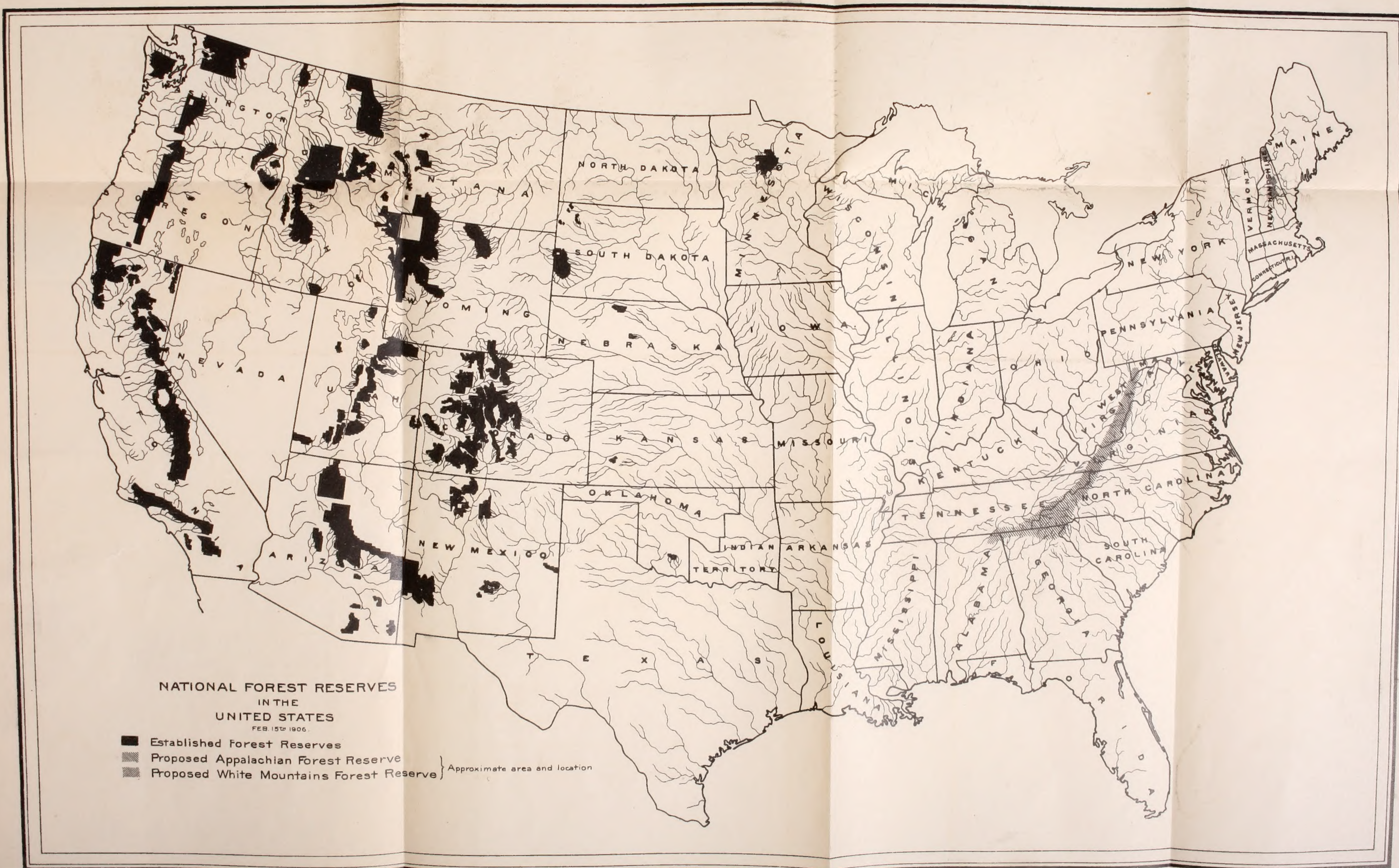





\section{LIBRARY OF CONGRESS}

||||||| || |||||||||||||||||||||||||||||||| 